\title{
RESPON BERBAGAI CARA PEMBERIAN KONSENTRAT DAN \\ RUMPUT RAJA TERHADAP PERTUMBUHAN SAPI BALI DI NIMBOKRANG KABUPATEN JAYAPURA
}

\author{
Budiono, Ones Yoku dan Freddy Pattiselanno'
}

\section{INTISARI}

Penelitian ini bertujuan untuk memperoleh cara pemberian konsentrat dan rumput Raja yang memberikan respon paling baik terhadap pertumbuhan sapi Bali. Penelitian menggunakan metode eksperimen yang didesain menurut Rancangan Bujur Sangkar Latin $5 \times 5$ yang terdiri atas 5 periode dengan menggunakan 5 ekor ternak sapi Bali sehingga jumlah keseluruhan adalah 25 unit satuan percobaan. Perlakuan yang diberikan adalah R1 : rumput raja $(100 \%)$, R2 : rumput raja $(70 \%)+$ konsentrat $(30 \%)$ yang diberikan bersama-sama; R3 : rumput raja $(70 \%)+$ konsentrat $(30 \%)$ diberikan bersama pada tempat yang terpisah; R4 : rumput raja $(70 \%)$ yang diberikan dua jam setelah ternak mengkonsumsi konsentrat $(30 \%)$ dan R5 : rumput raja $(70 \%)+$ konsentrat $(30 \%)$ yang diberikan dua jam setelah ternak mengkonsumsi rumput raja. Hasil yang diperoleh menunjukkan bahwa rataan pertambahan berat badan ternak sapi berada pada kisaran 0,380 0,700 kilogram, dengan pertambahan berat badan yang paling tinggi diperoleh perlakuan R3. Sebaliknya pemberian rumput raja tanpa penambahan konsentrat (perlakuan R1) memberikan respon yang paling baik terhadap efisiensi penggunaan pakan.

(Kata kunci : Rumput Raja, Sapi Bali, Pertumbuhan Nimbokrang Jayapura)

\section{RESPONCE OF THE VARIETY METHODS ON CONCENTRATE AND KING GRASS FEEDING TO THE BAI.I CATTLE GROWHT IN NIMBOKRANG JAYAPIRA}

\begin{abstract}
Two considerations related to fecding methods are : 1) concentrate should be given by mixing with grass together (Owen, 1979), and 2) concentrate should be given two hours before grass (Siregar, 1994). The aims of this research is to find an appropriate methods by studying the growth response of Bali cattle which given the variety of feeding methods. King Grass and concentrate composed diets comparison was $70-30$ percentage. Five treatments were arrangement by Latin Square Design. This research consist of five periods by using five Bali cattle, so there are 25 experiment units. All treatments give the significance response to body weight and feed efficiency. However, King grass which given without concentrate creates better response to feed efficiency
\end{abstract}

(Key words : King Grass, Bali cattle, Growth Nimbokrang, Jayapura).

Buletin Peternakan 24 (2): $64-67,2000$

\footnotetext{
${ }^{1}$ Fakultas Pertanian Universitas Cendrawasih, Manokwari 98314.
} 


\section{Pendahuluan}

Pakan sangat berpengaruh terhadap produksi ternak sehingga penanganan pakan perlu mendapat perhatian yang serius baik kualitas maupun kuantitasnya. Ibrahim (1988) menyatakan bahwa keuntungan penggunaan limbah pertanian dengan konsentrat sebagai bahan pakan ternak, yaitu mengurangi waktu ternak melakukan ruminansia, sehingga meningkatkan waktu istirahat bagi ternak. Menurut Arora (1989) ternak ruminansia yang diberi pakan berupa biji-bijian yang berenergi tinggi dalam jumlah yang banyak akan mengakibatkan menurunnya sekresi saliva ke dalam rumen, sehingga rumen kekurangan bahan buffer dan cenderung bersifat asam yang pada akhirnya akan merugikan organisme rumen. Oleh karena itu Bandini (1997) menegaskan bahwa penggunaan pakan yang berkualitas serta penangganan yang tepat akan memberikan kesempatan bagi ternak untuk mengembangkan kemampuan genetiknya semaksimal mungkin.

Oleh karena itu teknik pemberian pakan juga perlu diperhatikan dalam kaitannya dengan suplementasi konsentrat selanjutnya, untuk meningkatkan kecernaan bahan organik ransum, pemberian konsentrat sebainya dilakukan dua jam sebelum pemberian hijauan, tetapi menurut Owen (1979), konsentrat dapat diberikan secara bersama-sama dengan hijauan sebagai pakan lengkap. Hal ini sejalan dengan pendapat Ibrahim (1988), pada pemberian antara hijauan dan konsentrat secara bersamasama dalam bentuk campuran yang seragam, akan meningkatkan nilai guna hijauan yang diberikan, terutama bila hijauan yang diberikan berkualitas rendah.

Atas dasar perbedaan kedua pendapat tersebut, maka penelitian tentang cara pemberian pakan ini dirasa perlu untuk dilakukan. Diharapkan penelitian ini akan memberikan informasi tentang respon pertumbuhan sapi Bali dengan berbegai cara pemberian konsentrat dan rumput Raja. Selain itu diharapkan penelitian ini akan memberikan pengetahuan praktis yang bersifat aplikatif bagi petani/ peternak sapi Bali di Irian Jaya.

\section{Materi dan Metode}

Penelitian dilaksanakan di Kecamatan Nimbokrang Kabupaten Jayapura pada bulan Februari sampai dengan Juni 1999. Lima ekor sapi Bali jantan dewasa berumur 12 bulan dengan rataan berat badan $106 \mathrm{~kg}$ digunakan dalam penelitian ini, Penelitian terdiri atas 5 (lima) periode, dan setiap periode terdiri atas tujuh hari tahap penyesuaian dan 4 hari tahap pengumpulan data. Bahan pakan yang digunakan adalah konsentrat dengan formulasi dedak pada $(45 \%)$, tepung jagung $(40 \%)$, tepung kedelai $(14 \%)$ dan garam (1\%) serta hijauan rumput Raja.

Penelitian dirancang dengan menggunakan metode eksperimen mengikuti pola Rancangan Bujur Sangkar Latin (5X5) sehingga diperoleh 25 satuan percobaan Perlakuan yang diberikan dalam penelitian ini adalah RI $=$ Rumput Raja $(100 \%), \mathrm{R} 2=$ Rumput Raja (70\%) + Konsentrat $(30 \%)$ dicampur dan diberikan bersama-sama, R3 = Rumput Raja $(70 \%)$ + Konsentrat $(30 \%)$ diberikan terpisah dalam waktu bersamaan, R4 = Rumput Raja (70\%) + Konsentrat $(30 \%)$ pemberian Rumput Raja dilakukan dua jam setelah ternak mengkonsumsi konsentrat diberikan dua jam setelah ternak mengkonsumsi Rumput Raja.

Peubah yang diamati dalam penelitian ini yaitu pertambahan berat badan dan efisiensi penggunaan pakan. Data yang diperoleh dianalisis variansi dengan Rancangan Bujur Sangkar Latin. Uji Beda Nyata Jujur akan digunakan untuk menguji perlakuan yang menunjukkan pengaruh (Gasperz, 1991).

\section{Hasil Dan Pembahasan}

\section{Pertambahan berat badan}

Berdasarkan data pada Tabel 1. ternyata bahwa pertambahan berat badan tertinggi dicapai oleh ternak percobaan yang diberikan ransum perlakuan $\mathrm{R} 4(0,70 \mathrm{~kg} / \mathrm{hari})$, sedangkan 
yang terendah yaitu perlakuan R2 $(0,38$ $\mathrm{kg} / \mathrm{hari}$ ). Hasil analisa sidik ragam menunjukkan bahwa perlakuan yang diberikan memberi pengaruh yang sangat nyata $(P<0,01)$, terhadap pertambahan berat badan ternak.

Berdasarkan uji beda nyata jujur, te rlihat adanya perbedaan pada perlakuan R2, P3 dan R4. Hal ini memberikan indikasi uahwa dalam penelitian ini pemberian konsentrat yang dicampur dengan hijauan menghasilkan pertambahan berat badan yang le sih rendah dari perlakuan lainnya terutama perlakuan D3. Menurut Utomo dan Soedjono (1591), konsentrat yang diberikan bersama-sama hijaun tidak berpengaruh banyak terhadap kehidupan mikroorganisme rumen. Adanya konsentrat bersama-sama hijauan dalam rumen di duga dapat mengurangi populasi bakteri selulolitik, tetapi meningkatkan bakteri milolitik sehingga menurunkan kecernaan selulosa

Selanjutnya menurut laporan Siregar (1994), konsentrat yang diberikan bersamasama dengan hijauan akan mengakibatkan penurunan kecernaan bahan kering dan bahan organik pakan. Akibat menurunnya kecernaan bahan kering dan bahan organik, maka pertambahan berat badan harian akan menjadi rendah Disamping Wardhani dan Musofie (1991) menjelaskan bahwa pertambahan berat badan merupakan ekspresi dari kecernaan zatzat makanan. Artinya kecernaan zat-zat makanan dari bahan makanan yang dikonsumsi ternak mempunyai hubungan yang positif terhadap pertambahan berat badan.
Kisaran pertambahan berat badan dalam penelitian ini antara $0,36-0,70 \mathrm{~kg}$ ternyata lebih tinggi dibandingkan hasil penelitian Kuswardhono (1979) dalam Pongsapan dan Tangdilintin (1992), pada penggemukan sapi Bali dengan bahan pakan rumput, leguminosa dan konsentrat yang menghasilkan pertambahan berat badan $0,344 \mathrm{~kg}$.

\section{Efisiensi pakan}

Nilai efisiensi pakan yang dihasilkan ternak percobaan berkisar antara 0,147 (perlakuan R2) sampai 0,254 (perlakuan R1). dengan rata-rata nilai keseluruhan adalah 0,183 . Hasil analisa sisik ragam menunjukkan bahwa perlakuan memberikan pengaruh yang sangat nyata $(P<0.01)$ terhadap efisiensi pakan.

Berdasarkan uji beda nyata jujur diketahui bahwa perlakuan R2, R3 R4 dan R5 memberikan perbedaan yang sangat nyata lebih rendah dari perlakuan R1.

Efisiensi pakan yang dihasilkan pada penelitian ini relatif lebih tinggi dibandingkan dengan penelitian Pongsapan dan Tangdilintin (1992) yang menggunakan sapi Bali yang berumur 24 bulan dengan pemberian pakan rumput alam dan ampas sagu. Lebih tingginya nilai efisiensi ini di duga karena faktor umur ternak dan jenis pakan yang digunakan dalam penelitian ini $\mathrm{Hal}$ ini didukung oleh pernyataan Moran (1978) dalam Bandini (1997), bahwa temak sapi Bali pada umur 12 18 bulan apabila diberi pakan penguat berupa konsentrat akan menghasilkan pertambahan

Tabel 1. Rataan pertambahan berat badan dan efisiensi penggunaan pakan dari masingmasing perlakuan per ekor per hari (Average daily gain and feed

$$
\text { efficiency for each (reaiment group) }
$$

\begin{tabular}{|c|c|c|c|c|c|}
\hline \multirow[t]{2}{*}{ Pengamatan (Observation) } & \multicolumn{5}{|c|}{ Perlakuan (Treatment) } \\
\hline & R1 & $\mathrm{R} 2$ & R3 & R4 & R5 \\
\hline $\begin{array}{l}\text { Pertambahan berat badan } \\
\text { (Average daily gain) }\end{array}$ & $0.51^{\mathrm{Ac}}$ & $0.380^{\mathrm{a}}$ & $0.690^{\circ}$ & $0.700^{\mathrm{hc}}$ & $0.520^{2 \mathrm{C}}$ \\
\hline $\begin{array}{l}\text { Efisiensi penggunaan pakan } \\
\text { (Feed efficiency) }\end{array}$ & $0.25^{\circ}$ & $0.147^{\mathrm{a}}$ & $0.192^{\mathrm{ath}}$ & $0.167^{\mathrm{abc} c}$ & $0.152^{\text {th }}$ \\
\hline
\end{tabular}


berat badan sebesar $0,87 \mathrm{~kg}$ sehingga efisiensi penggunaan pakannya lebih baik.

\section{Kesimpulan}

Semua cara pemberian konsentrat dengan rumput Raja memberikan respon yang nyata terhadap konsumsi bahan kering pakan, pertambahan berat badan dan efisiensi penggunaan pakan. Pemberian rumput Raja tanpa konsentrat memberikan respon yang lebih tinggi terhadap tingkat efisiensi pakan ¿ibanding cara pemberian rumput Raja dengan konsent at

\section{Daftar Pustaka}

Arora, S P 1989 Pencernaan Mikrobia pada Ruminansia Gadjah Mada University Press, Yogyakarta.

Bandini. Y, 1997 Sapi Bali. Penebar Swadaya, Jakarta.

Gasperz, V. 1991. Metode Perancangan Percobaan. Armico, Jakarta.

Ibrahim, M. N. M. 1998. Von-conventional Feed Resources and Fibrous Agricul- ture Residues Strategies for Expand Utilization. International Development Research Center Indian Council of Agriculture Research, India.

Owen, J. B. 1979. Complete Diets for Cattle and Sheep. Farming Press Ltd, Suffolk, England.

Pongsapan, P dan F. K. Tangdilintin. 1992. Pengaruh berbagai tingkat ampas sagu dalam ransum terhadap pertumbuhan sapi Bali. Jipnak Gowa Vol. 1:1 BPPP Departermen Pertanian.

Siregar, S, B, 1994, Ransum Ternak Ruminansia. Penebar Swadaya, Jakarta.

Utomo dan Soedjono. 1991. Pengaruh Waktu Pemberian Konsentrat terhadap Pertumbuhan Sapi Peranakan Ongole. Seminar Nasional Pengembangan Sapi Potong di Indonesia, Bandar Lampung.

Wardhani, N. K. dan A. Musofie. 1991. Jerami jagung segar, kering dan teramoniasi sebagai pengganti hijauan pada sapi potong. Jipnak Grati Vol. 2 : 1BPPP Departemen Pertanian. 